Rev.MVZ Córdoba 19(3):4195-4198, 2014. ISSN: 0122-0268

\title{
EDITORIAL
}

\section{Ebola... How far away are we?}

\author{
Ébola... ¿Qué tan lejos estamos?
}

Hollywood adores an infectious disease film. One of the most shocking was the 1995 film "Outbreak", in which Dustin Hoffman and Rene Russo worked to stop a fictional virus similar to Ebola. In the movie the virus is introduced from Africa to the US by a monkey. In another film, "28 Days Later," a virus from experimental monkeys infects humans in London. Several additional films about the human fear of "killer viruses" have been released. A real-life scare to the US and the western world came when two American Ebola patients were recently transported from West Africa to an Atlanta hospital for treatment. Currently, there is a pervasive public fear of the dissemination of Ebola in the US and the rest of the world.

Ebola virus causes a severe, often fatal hemorrhagic fever, with a case fatality rate of up to $90 \%$. Ebola virus is one of the world's most virulent pathogens. The virus is transmitted by direct contact with the blood, body fluids, and tissues of infected animals or humans. Severely ill patients require intensive supportive care. During an outbreak, those at highest risk of infection are health workers, family members, and others in close contact with sick or deceased patients. The estimated number of cases in the current outbreak in West Africa is 3069 with 1552 deaths (51\% mortality) $(1,2)$.

In 1976, Ebola virus was first detected during two simultaneous outbreaks in Sudan and the Democratic Republic of the Congo (then Zaire). The village in which the second outbreak occurred is near the Ebola River, which gives its name to the virus. The family Filoviridae contains three genera: Ebolavirus, Marburgvirus, and Cuevavirus. Ebolavirus contains five species: Bundibugyo ebolavirus, Zaire ebolavirus, Reston ebolavirus, Sudan ebolavirus, and Tai Forest ebolavirus. Bundibugyo ebolavirus, Zaire ebolavirus, and Sudan ebolavirus have been associated with major outbreaks in Africa. Reston ebolavirus,
A Hollywood le gustan las películas de enfermedades infecciosas. Una de las más impactantes fue la película "Brote" en 1995, en donde Dustin Hoffman y Rene Russo se esforzaron para detener un ficticio virus similar al Ébola. En la película el virus es introducido desde África a los Estados Unidos por un mono. En otra película, "28 días después", un virus de monos experimentales infecta a los humanos en Londres. Otras películas se han realizado sobre el miedo humano a los "virus asesinos". El miedo se hizo realidad en los Estados Unidos y en el mundo occidental cuando dos pacientes estadounidenses enfermos de Ébola fueron recientemente transportados desde África occidental hasta un hospital en Atlanta con el fin de recibir tratamiento. En la actualidad, en la gente existe un temor generalizado de la difusión del Ébola en los Estados Unidos y en el resto del mundo.

El virus del Ébola provoca una fiebre hemorrágica severa, a menudo fatal, con una tasa de letalidad de hasta $90 \%$. El virus de Ébola es uno de los patógenos más virulentos de todo el mundo. El virus se transmite por contacto directo con la sangre, fluidos corporales y tejidos de animales infectados o de seres humanos. Los pacientes gravemente enfermos necesitan servicios de cuidado intensivo. Durante un brote, el mayor riesgo de infección lo tienen los trabajadores de la salud, miembros de la familia y otros que están en estrecho contacto con pacientes enfermos o fallecidos. El número estimado de casos en el brote actual en África occidental es 3069 con 1552 muertes (51\% de mortalidad) $(1,2)$.

En 1976, el virus del Ébola fue primero detectado durante dos brotes simultáneos en Sudán y la República Democrática del Congo (antes Zaire). La aldea en la que se produjo el segundo brote está cerca del Río Ébola, que da su nombre al virus. La familia Filoviridae contiene tres géneros: Ebolavirus, Marburgvirus y Cuevavirus. Ebolavirus contiene cinco especies: Bundibugyo ebolavirus, Zaire ebolavirus, Reston ebolavirus, Sudán ebolavirus y Tai forest ebolavirus. Bundibugyo ebolavirus, ebolavirus de Zaire y Sudán ebolavirus se han asociado con grandes brotes en África. 
found in the Philippines and China, can infect humans, but is not known to cause human disease (3).

Spillover of Ebola virus from the endemic wildlife cycle to humans may occur through contact with organs, blood, secretions, or body fluids of an infected animal. In Africa human infection has been associated with handling infected chimpanzees, gorillas, monkeys, fruit bats, and porcupines. Once introduced to humans, the virus spreads in the community by human-to-human transmission as described above. In Africa, burial ceremonies in which the members of the funeral procession have direct contact with the corpse can also result in transmission. Men can continue to transmit the virus in semen for seven weeks after clinical recovery $(3,4)$.

Investigators in Canada showed the deadly virus may spread between species, through the air. A team of researchers from the National Centre for Foreign Animal Disease, the University of Manitoba, and the Public Health Agency of Canada, observed transmission of Ebola virus from pigs to monkeys. They inoculated piglets with the virulent Zaire Ebolavirus. The piglets were placed in a room with macaques, but were separated by wire cages to prevent direct contact between the species. A few days later the inoculated piglets showed clinical signs of infection. In pigs, Ebola generally causes respiratory illness and increased temperature. After eight days of exposure, monkeys showed signs of Ebola infection (5).

Ebola hemorrhagic fever is often characterized by sudden onset of fever $\left(40^{\circ} \mathrm{C}\right)$, intense weakness and muscle aches, headache and sore throat, followed by vomiting, diarrhea, rash, renal and hepatic dysfunction and, in some cases, internal and external bleeding. Laboratory results show leucopenia, thrombocytopenia, and elevated liver enzymes. Patients are contagious as long as the virus is present in blood and secretions. The incubation period (interval from infection to onset of symptoms) varies between 2 and 21 days (3).

There is no vaccine for Ebola virus. Some vaccine candidates are being tested but none are yet available for clinical use. Most cases require treatment in an intensive care unit. Patients tend to be dehydrated and need intravenous or oral rehydration with electrolyte solutions. There is no specific
Reston ebolavirus, encontrado en las Filipinas y China, puede infectar a los seres humanos, pero no se sabe si causa enfermedad en humanos (3).

El contagio del virus del Ébola del ciclo endémico de vida silvestre a los seres humanos puede ocurrir a través del contacto con los órganos, sangre, secreciones o fluidos corporales de un animal infectado. En África la infección humana se ha asociado con el manejo de los chimpancés infectados, gorilas, monos, murciélagos frugívoros y puercos espines. Una vez introducido a los seres humanos, el virus se propaga en la comunidad por la transmisión de humano a humano como se describió anteriormente. En África, las ceremonias funerales en las cuales, miembros de la comitiva fúnebre tienen contacto directo con el cuerpo también pueden resultar infectados. Los hombres pueden seguir transmitiendo el virus en el semen durante siete semanas después de la recuperación clínica $(3,4)$.

Investigadores en Canadá demostraron que el virus mortal se puede diseminar entre las especies, a través del aire. Un equipo de investigadores del Centro Nacional para Enfermedades Animales Exóticas, la Universidad de Manitoba y la Agencia de Salud Pública de Canadá, observaron la transmisión del virus del Ébola los cerdos a los monos. Inocularon lechones con la cepa virulenta Ebolavirus de Zaire. Los lechones fueron colocados en una sala con los macacos, pero fueron separados por jaulas metálicas para evitar el contacto directo entre las especies. Unos días más tarde los cerdos inoculados mostraron signos clínicos de infección. En cerdos, el Ébola generalmente causa enfermedad respiratoria e incremento de la temperatura. Después de ocho días de exposición, los monos mostraron signos de infección por el virus del Ébola (5).

La fiebre hemorrágica del Ébola se caracteriza por la aparición súbita de fiebre $\left(40^{\circ} \mathrm{C}\right)$, debilidad intensa, dolores musculares, dolor de cabeza, dolor de garganta, seguido por vómitos, diarrea, erupción cutánea, disfunción renal y hepática, y en algunos casos, sangrados internos y externos. Los resultados de laboratorio muestran niveles elevados de enzimas hepáticas, trombocitopenia y leucopenia. Los pacientes son contagiosos mientras el virus esté presente en la sangre y en las secreciones. El período de incubación (intervalo de la infección con aparición de síntomas) varía entre 2 y 21 días (3).

No hay vacuna para el virus del Ébola. Algunas vacunas candidatas están siendo analizadas, pero todavía ninguna está disponible para uso clínico. La mayoría de los casos requieren de tratamiento en una unidad de cuidados intensivos. Los pacientes tienden a deshidratarse y necesitan 
treatment, though new drug treatments are being evaluated. According to a report published online in Science Translational Medicine, scientists have successfully treated Ebola virus infection in animals following onset of disease. The results show promise for developing therapies. MB-003 is a "cocktail" of monoclonal antibodies that help bind to and inactivate the virus. The antibodies recognize infected cells and trigger the immune system to destroy them. No side effects of the antibodies were seen in the surviving animals. Recently, WHO authorized human treatment with MB-003 (6); two American patients survived and one Spanish priest died.

The natural hosts of the Ebola viruses are likely to be fruit bats such as Hypsignathus monstrosus, Epomops franqueti, and Myonycteris torquata, which are common in Africa (7). There are no studies in Latin America on Ebola, but if the evolution of the filovirus is as old as American bats ( 500 million years), one could speculate that some filoviruses might be present in the Neotropics. The geographic distribution of Ebola viruses could match the distribution of these bats, or other unknown neotropic filoviruses could be adapted to other autochthonous bat species.

Although non-human primates have been a source of infection for humans, it is believed that they are not the reservoir of the virus. More likely, they are accidental guests, like humans. Outbreaks of Ebola in chimpanzees and gorillas have been reported. The virus has caused severe outbreaks in crab eating macaques (Macaca fascicularis) in the Philippines, and was detected in monkeys imported from the Philippines to the US and Italy in the 1990s. In 2008, Ebola virus was detected in several outbreaks of deadly disease in pigs in the Philippines and China. Asymptomatic infections in pigs have also been reported (7).

In Colombia, we should be alert to illegal immigration of humans from Ebola-endemic countries who use Colombia as a bridge to reach America and the US. Colombian immigration officials must be alert to international passengers who may be sick with high fever. Finally, studies of bat ecology are also important. rehidratación intravenosa u oral con soluciones electrolíticas. No hay ningún tratamiento específico, aunque se están evaluando nuevos tratamientos farmacológicos. Según un informe publicado en Science Translational Medicine, los científicos han tratado con éxito la infección del virus del Ébola en animales luego de la aparición de la enfermedad. Los resultados son prometedores para el desarrollo de terapias. El MB-003 es un "cóctel" de anticuerpos monoclonales que ayudan a capturar e inactivar el virus. Los anticuerpos reconocen las células infectadas y activan el sistema inmunitario para destruirlos. No hubo efectos secundarios de los anticuerpos en los animales sobrevivientes. Recientemente, la Organización Mundial de la Salud autorizó el tratamiento humano con MB-003 (6); dos pacientes americanos sobrevivieron y un sacerdote español quien murió.

El huésped natural de los virus del Ébola es probable que sean los murciélagos frugívoros como Hypsignathus monstrosus, Franqueti Epomops y Myonycteris torquata, que son comunes en África (7). No existen estudios en América Latina del Ébola, pero, si la evolución de los filovirus es tan antigua como los murciélagos americanos (500 millones de años), se podría especular que algunos filovirus podrían estar presentes en el neotrópico. La distribución geográfica del virus del Ébola podría coincidir con la distribución de estos murciélagos u otros desconocidos filovirus neotropicales podrían adaptarse a otras especies autóctonas.

Aunque los primates no humanos han sido una fuente de infección para los seres humanos, se cree que no son el reservorio del virus. Lo más probable es que sean huéspedes accidentales, como los seres humanos. Se han reportado brotes de Ébola en chimpancés y gorilas. El virus ha causado brotes severos en macacos cangrejeros (Macaca fascicularis) en las Filipinas y fue detectado en monos importados de Filipinas a los Estados Unidos e Italia en la década de 1990. En 2008, el virus del Ébola fue detectado en varios brotes de enfermedad mortal en los cerdos en las Filipinas y China. También se han reportado infecciones asintomáticas en cerdos (7).

En Colombia, deberíamos estar alertas a la inmigración ilegal de personas de los países endémicos del Ébola, que utilizan a Colombia como puente para llegar a América y luego a los Estados Unidos. Los funcionarios colombianos de inmigración, deben estar alertas con los pasajeros internacionales que pueden estar enfermos con fiebre alta. Finalmente, los estudios de ecología de murciélagos también son importantes. 


\section{REFERENCES}

1. Centers for Disease Control and Prevention. 2014 Ebola Outbreak in West Africa. [on line]. Atlanta, USA: CDC; 2014. URL Available in: http://www.cdc.gov/vhf/ebola/ outbreaks/guinea/index.html

2. Centers for Disease Control and Prevention. Ebola Hemorrhagic Fever. [on line]. Atlanta, USA: CDC; 2014. URL Available in: http://www.cdc.gov/vhf/ebola/index. html?s_cid=cdc_homepage_feature_001

3. World Health Organization. Global Alert and Response (GAR). [on line]. Geneva, Switzerland: WHO; 2014. URL Available in: http://www.who.int/csr/disease/ebola/en/

4. Centers for Disease Control and Prevention. Signs and Symptoms. [on line]. Atlanta, USA: CDC; 2014. URL Available in: http://www. cdc.gov/vhf/ebola/symptoms/index.html
5. Jane Huston. From Pigs to Monkeys, Ebola Goes Airborne. [on line]. The Disease Daily 2012. URL Available in: http://healthmap. org/site/diseasedaily/article/pigs-monkeysebola-goes-airborne-112112

6. World Health Organization. Ebola: Experimental therapies and rumoured remedies. [on line]. Geneva, Switzerland: WHO; 2014. URL Available in: http:// www.who.int/mediacentre/news/ebola/15august-2014/en/

7. World Health Organization. Ebola: Media centre. [on line]. Geneva, Switzerland: WHO; 2014. URL Available in: http://www. who.int/mediacentre/factsheets/fs103/en/ 